\title{
Comparison of ovulation induction and pregnacy outcomes in IVF patients with normal ovarian reserve who underwent long protocol with recombinant-FSH and highly purified-hMG
}

\author{
Normal over rezervi olan ve long protokol uygulanan IVF hastalarinda \\ rekombinant fsh ve yüksek derecede saflaştırlmıs hmg kullanımının gebelik \\ sonuçlarına etkisinin karşıllaştırılması
}

Cem Çelik ${ }^{1}$, Kenan Sofuoğlu², Selçuk Selçuk², Mehmet Reşit Asoğlu², Remzi Aball ${ }^{1}$, Elçin Çetingözz ${ }^{2}$, Bahar Baykal' ${ }^{2}$ Mehmet Uludoğan²

'Department of Obstetrics and Gynecology, Namik Kemal University, Tekirdag, Turkey

${ }^{2}$ Department of Obstetrics and Gynecology, Zeynep Kamil Training and Education Hospital, Istanbul, Turkey

\section{Abstract}

Objective: Gonadotropins used in controlled ovarian stimulation have been increasing in number. Beside the recombinant preparations such as rec-FSH, rec-LH and h-hMG human-derived preparations have entered the market. We decided to compare the effects of rec-FSH and HP-hMG with GnRHa on embryo quality and pregnancy outcome in women undergoing an IVF cycle.

Material and Methods: In this study, data of 87 patients who had applied to our center from 2007 to 2008 and who had met all inclusion criteria, were analyzed. The patients underwent controlled ovarian hyperstimulation with HP-hMG, rec-FSH following down-regulation with a GnRHa in a long protocol, selected according to determined criteria and acquired embryo via IVF transfer.

Results: Of the 87 patients, 44 were stimulated with rec-FSH and 43 with HP-hMG. Distribution of infertility causes was similar between the groups. Duration of gonadotropin administration $(p=0.677$, Student's t-test) and the total dose of gonadotropin received ( $p=0.392$, Student's t-test) were similar between the two groups. The fertilization rate of the rec-FSH group was significantly higher than the HPhMG group ( $p=0.001$, Mann-Whitney U test). No significant differences were observed between the study groups in biochemical, clinical and ongoing pregnancy parameters.

Conclusion: The higher oocyte yield with rec-FSH does not result in higher quality embryos. LH activity in combination with FSH activity positively affected the oocyte and embryo maturation. Therefore, when we consider the clinical and ongoing pregnancy rates there is no inferiority of HP-hMG in controlled ovarian stimulation.

(J Turkish-German Gynecol Assoc 2011; 12: 15-20)

Key words: Ovarian stimulation, rec-FSH, HP-hMG

Received: 2 January, 2011

Accepted: 23 February, 2011
Özet

Amaç: Son dekatta ovulasyon indüksiyonu ve kontrollü over stimülasyonu için kullanılan gonadotropinler hızla çoğalmıştır. Çeşitli rekombinant preperatların yanında; rec-FSH, rec-LH, insan kaynaklı gonadotropinlerde pazara girmiştir. Bu çalışmadaki amaç; in vitro fertilizasyon protokolünde yer alan rec- FSH ve HP-hMG'nin elde edilen embriyoların kalitesi ve gebelik sonuçları üzerindeki etkilerinin karşılaştırılmasıdır.

Gereç ve Yöntemler: Çalışmamıza 2007- 2008 tarihleri arasında Zeynep Kamil kadın ve çocuk hastalıkları eğitim ve araştırma hastanesi tüp bebek merkezine başvuran, çalışmaya dahil edilme kriterlerini sağlayan 87 hastanın verileri kullanıldı. Belirlenen kriterlere göre seçilen, ovulasyon indüksiyonu için rec-FSH ve/veya HP-hMG kullanarak uzun protokol agonist tedavi protokolleri uygulanmış; IVF yöntemi ile ovum fertilizasyonu sağlanmış ve elde edilen embriyolarla transfer yapılmıştır.

Bulgular: Olgular rec-FSH ( $n=44)$ ve HP-hMG $(n=43)$ olmak üzere iki grup altında incelenmiştir. İnfertilite nedenlerin dağılımı her iki grup arasinda benzer olarak bulunmuştur. Gruplara göre olgulara uygulanan total gonadotropin dozları ( $p=0.677$, Student t-test) ve süresi $(p=0.392$, Student t-test) arasında istatistiksel olarak anlamlı bir farklılık bulunmamaktadır. Rec-FSH grubundaki olguların fertilizasyon sayıları, HP-hMG grubundaki olguların fertilizasyon sayllarından istatistiksel olarak ileri düzeyde anlamlı fazladır $(\mathrm{p}<0.01)$. rec-FSH ve HP-hMG gruplarında kimyasal gebelik, klinik ve devam eden gebelik görülme oranları arasında istatistiksel olarak anlamlı bir farklılık bulunmamaktadır.

Sonuç: rec-FSH grubunda yüksek oosit sayısı olmasına rağmen yüksek kalitede embriyo sayısı elde edilmemiştir. FSH aktivitesi ile birlikte LH aktivitesi oosit ve embriyo gelişimini pozitif yönde etkilemiştir. Bu sebepten dolayı klinik ve devam eden gebelik oranlanı incelendiğinde, HP-hMG grubunda herhangi bir düşüş rastlanılmamıştır.

(J Turkish-German Gynecol Assoc 2011; 12: 15-20)

Anahtar kelimeler: Ovulasyon indüksiyonu, rec-FSH, HP-hMG

Geliş Tarihi: 02 Ocak 2011

Kabul Tarihi: 23 Şubat 2011 


\section{Introduction}

Controlled ovarian stimulation in infertile women undergoing treatment for in vitro fertilization (IVF) have usually been provided with highly purified human menopausal gonadotropin (HP-hMG), including both luteinizing hormone (LH) and follicle-stimulating hormone (FSH) activity and recombinant FSH (rec-FSH). Decision as to the most effective preparations between HP-hMG and rec-FSH is a common debatable issue (1). Comparing the outcome of rec-FSH and HP-hMG performed in women undergoing pituitary down-regulation with a gonadotropin-releasing hormone agonist (GnRHa), long protocol has been reported in several studies (2). However, the meta-analysis concluded that large randomized trials were needed to precisely estimate any difference between menotrophins and rec-FSH (1).

Results of various studies based on the role of exogenous $\mathrm{LH}$ in the process of follicular development, oocyte maturation, and pregnancy rate have raised another argument (3). The concentration of circulating $\mathrm{LH}$ that results from the combination of GnRHa and recombinant FSH is much lower than that found in the normal menstrual cycle (4). The lowered basal LH secretion that results from the use of GnRHa, together with the absence of exogenous LH in rec-FSH preparations, may contribute to a decreased PR in IVF (5-8). On the other hand, other studies indicate that very low amounts of LH maintain development of normal follicle and oocyte (9). Moreover, high serum LH during the follicular phase of the menstrual cycle has been associated with lower fertility rates and an increase in the probability of spontaneous abortion (10).

The aim of the present study was to prove the superiority of HP-hMG versus rec-FSH in a relevant clinical setting. We decided to compare the effect of rec-FSH and HP-hMG with GnRHa on embryo quality and pregnancy outcome in women undergoing an IVF cycle. Results were discussed in the light of recent insights on the effects of $\mathrm{LH}$ activity on folliculogenesis, embryo quality and endometrial development.

\section{Materials and Methods}

The patients underwent controlled ovarian hyperstimulation with HP-hMG, rec-FSH following down-regulation with a GnRHa in a long protocol, selected according to determined criteria and acquired embryo via IVF transfer. Comparing the effectiveness of performed protocols was the retrospective aim. In this study, data of 87 patients who had applied to our center from 2007-2008 and who had met all inclusion criteria, were analyzed.

Inclusion criteria were: primary or secondary infertile women with major indications for IVF, age 20-40 years, body mass index (BMI) $18-29 \mathrm{~kg} / \mathrm{m}^{2}$, regular menstrual cycles ranging from 25 to 35 days, normal basal serum FSH ( $<13$ IU/1) and estradiol $\left(\mathrm{E}_{2}<75 \mathrm{pg} / \mathrm{ml}\right)$ levels determined on day 3 of the cycle, normal basal serum thyroid stimulating hormone (TSH) and prolactin, no uterine (fibroids, adenomyosis, mullerian malformations), ovarian (endometrioma, polycystic ovaries), or adnexal (hydrosalpinx) abnormalities assessed by transvaginal ultrasonograghy.
Exclusion criteria were: patients with a history of recurrent pregnancy loss, history of ovarian hyperstimulation syndrome (OHSS) at previous IVF cycles, previous IVF cycles with unsuccessful fertilization polycystic ovary syndrome, stage 4/5 endometriosis, any significant systemic disease, endocrine, or metabolic disorder.

\section{Cycle cancellation criteria}

Unsuccessful fertilization, after ovulation induction, all follicles less than $18 \mathrm{~mm}$ in diameter decreasing at serum $\mathrm{E}_{2}$ level of more than $50 \%$ between two control days, existence of OHSS risk: on stimulation day $8 ; 15$ or more intermediate follicles (12-16 $\mathrm{mm}$ ) or on stimulation day 10 or after; 20 or more large follicles (16-20 mm), and/or serum $\mathrm{E}_{2}$ level $\geq 3000 \mathrm{pg} / \mathrm{ml}$.

At the first visit, the obstetric and gynecologic history and menstrual cycle regularity were questioned and pelvic examination was performed. In addition, blood pressure, height, weight, and BMI were measured.

Blood sampling for fasting blood glucose, blood urea nitrogen, aspartate aminotransferase (AST), alanine aminotransferase (ALT), and thyroid function tests were carried out on menstrual cycle day 3.

Blood sampling for endocrine parameters (FSH, LH, hCG, $\mathrm{E}_{2}$, progesterone, androstenedione, total testosterone, and sex hormone-binding globulin) and basal ultrasonography for assessment of the endometrial thickness, ovarian size, number and diameter of follicles were carried out in the early follicular phase (on menstrual cycle day 2 or 3 ).

\section{Protocols}

All patients underwent controlled ovarian hyperstimulation following down-regulation with a GnRHa in a long protocol. About 44 patients were stimulated with rec-FSH (Puregon; Organon, Holland) and 43 patients with HP-hMG (Menopur, Ferring, Sweden).

All patients received an identical type and dose of concomitant fertility treatment, that is, GnRHa for down-regulation, human chorionic gonadotropin (hCG) for triggering final maturation, and progesterone for luteal support. Pituitary down-regulation using triptorelin acetate, $0.1 \mathrm{mg} /$ day s.c. (DECAPEPTYL; Ferring Pharmaceuticals A/S), was initiated 5-7 days before the estimated start of the next menses and continued until the end of gonadotropin administration. Gonadotropin administration was initiated when down-regulation was confirmed by using transvaginal ultrasonography showing no ovarian cysts, a shredded endometrium with a thickness of $<5 \mathrm{~mm}$ or serum estradiol $<50 \mathrm{pg} / \mathrm{ml}(0.184 \mathrm{nmol} / \mathrm{l})$. The starting dose of HP-hMG or rec-FSH was 225 IU for the first 5 days, followed by individual adjustments according to the patient's follicular response. The dose could be changed by 75 IU per adjustment and not more frequently than every 4 days. Choriogonadotropin alpha, 250 $\mu$ g s.c. (OVITRELLE; Serono) was administered to induce final follicular maturation within 1 day of observing three or more follicles of $\geq 17 \mathrm{~mm}$ diameter. Oocyte retrieval took place $36 \pm 2$ $\mathrm{h}$ after hCG administration.

Insemination was done via regular IVF insemination (not ICSI) at $3 \pm 1 \mathrm{~h}$ after oocyte retrieval. Fertilization was assessed at 
$20 \pm 1 \mathrm{~h}$, and embryo quality was assessed at $28 \pm 1 \mathrm{~h}, 44 \pm 1 \mathrm{~h}$, and $68 \pm 1 \mathrm{~h}$ after oocyte retrieval. A top-quality embryo was defined as four to five cells on day 2 (type A), seven or more cells on day 3 , equally sized blastomeres and $\leq 20 \%$ fragmentation on day 3 , and no multinucleation. The transfer of one or two embryos of minimum quality, defined as four or more cells with no cleavage arrest (i.e., cleavage must have occurred within the last $24 \mathrm{~h}$ and $\leq 20 \%$ fragmentation), was done on day 3 after oocyte retrieval. Vaginal progesterone gel $90 \mathrm{mg} /$ day $8 \%$ (CRINONE; Serono) for luteal support was given from the day of embryo transfer until the confirmation of clinical pregnancy (5-6 weeks after embryo transfer) or negative serum $\beta$-hCG test (13-15 days after embryo transfer).

Our primary aim was to compare the ongoing pregnancy per started cycle. Positive $\beta$-hCG test following embryo transfer was described as chemical pregnancy. Ongoing pregnancy was defined as positive heart beat 10-11 weeks after embryo transfer by ultrasonographic examination. Other outcome parameters assessed were HP-hMG/rec-FSH dose (IU: International Unit), days of gonadotropin stimulation, number of oocytes retrieved, fertilization rate, number of embryos, and ongoing pregnancy.

\section{Statistical analysis}

Dates of the study were analyzed by statistical package for social science for window 15.0. Summary statistics were evaluated for all parameters. Differences between groups of normally distributed variables were assessed with the Student's t-test, while not normally distributed variables were compared with the Mann-Whitney U test. Noncontinuous variables were compared with the Chi square test. $\mathrm{P}<0.05$ was considered statistically significant.

\section{Results}

Demographics and baseline characteristics of the participants are shown in the Table 1. No difference was observed between the two treatment groups. Distribution of infertility causes was similar between the groups (Figure 1). About 87 cases were reported in this study. Of the 87 patients, 44 were stimulated with rec-FSH and 43 with HP-hMG. Data of 87 patients were analyzed by dividing them into two groups as rec-FSH $(n=44)$ and HP-hMG $(n=43)$ treatments.

Duration of gonadotropin administration $(p=0.677$, Table 1) and the total dose of gonadotropin received $(p=0.392$, Table 2) were similar between the two groups. Serum $\mathrm{E}_{2}$ levels on the day of rec-hCG administration were different between the HP-hMG and rec-FSH group, which was statistically significant. Serum $E_{2}$ levels were higher in the HP-hMG group $(p=0.041$, Table 2 ). On the day of hCG injection, there was no significant difference in endometrial thickness $(p=0.282$, Table 2$)$. Oocyte retrieval was performed in 41 (95.3\%) patients stimulated with HP-hMG and in 43 (97.7\%) patients stimulated with rec-FSH. In the HP-hMG group, 2 patients did not attend the oocyte retrieval visit because of insufficient endometrial thickness (1 patient) and degenerated oocyte (1 patient). In the rec-FSH group, oocyte retrieval was not performed in 1 patient due to endometrial thickness. The mean

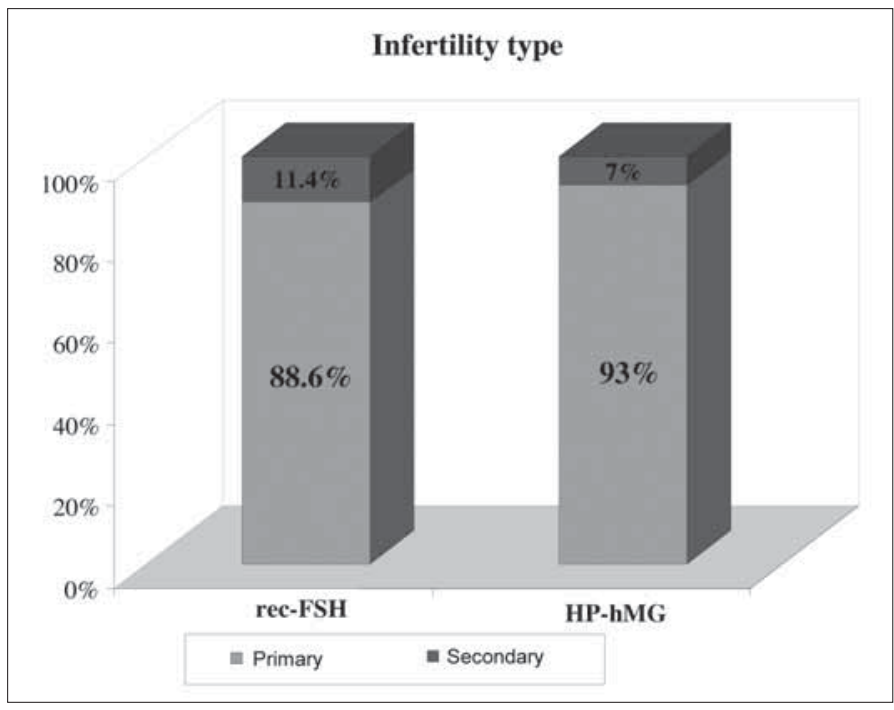

Figure 1. Distribution of infertility type in the groups

Table 1. Demographics and baseline characteristics of patients in the groups

\begin{tabular}{|c|c|c|c|c|}
\hline & & $\begin{array}{c}\text { rec-FSH } \\
\text { n (\%) }\end{array}$ & $\begin{array}{l}\text { HP-hMG } \\
\text { n (\%) }\end{array}$ & $\mathbf{p}$ \\
\hline \multirow{2}{*}{ Age } & $<35$ & $26(59.1)$ & $20(46.5)$ & \multirow{2}{*}{0.240} \\
\hline & $\geq 35$ & $18(40.9)$ & $23(53.5)$ & \\
\hline & & mean $\pm s d$ & mean $\pm s d$ & \\
\hline \multicolumn{2}{|c|}{ Weight (kg) } & $63.54 \pm 9.54$ & $65.44 \pm 9.38$ & 0.353 \\
\hline \multicolumn{2}{|c|}{ BMI $\left(\mathrm{kg} / \mathrm{m}^{2}\right)$} & $24.24 \pm 4.18$ & $25.17 \pm 3.40$ & 0.257 \\
\hline \multicolumn{2}{|c|}{ Antral follicles at day 1} & $10.58 \pm 3.98$ & $9.21 \pm 3.28$ & 0.087 \\
\hline \multicolumn{2}{|c|}{$\begin{array}{l}\text { Duration of infertility } \\
\text { (years) }\end{array}$} & $10.53 \pm 5.23$ & $10.14 \pm 5.00$ & 0.720 \\
\hline \multicolumn{2}{|c|}{ FSH (IU/I) at day 3} & $7.76 \pm 2.50$ & $8.09 \pm 2.24$ & 0.512 \\
\hline \multicolumn{2}{|c|}{$\mathrm{E}_{2}$ (IU/I) at day 3} & $59.97 \pm 22.37$ & $59.74 \pm 34.04$ & 0.970 \\
\hline \multicolumn{2}{|c|}{$\begin{array}{l}\text { Duration of GnRH } \\
\text { agonist (days) }\end{array}$} & $22.35 \pm 3.60$ & $21.63 \pm 3.58$ & 0.354 \\
\hline \multicolumn{2}{|c|}{$\begin{array}{l}\text { Duration of } \\
\text { Gonadotropin (days) }\end{array}$} & $9.37 \pm 1.46$ & $9.51 \pm 1.62$ & 0.677 \\
\hline
\end{tabular}

Chi square test was used for age $(\mathrm{p}<0.05)$. Student's t-test was used for other parameters $(\mathrm{p}<0.05$

number of oocytes retrieved was lower in the HP-hMG group compared with the rec-FSH group $(\mathrm{p}=0.029$, Table 3$)$. The mean number of oocytes fertilized was also lower in the HP-hMG group compared with the rec-FSH group $(p=0.001$, Table 3$)$. Between the study groups, there were no significant differences in the number of embryos on day 2 and 3 . The number of topquality embryos did not differ between the patients of the two groups, but the rate of top-quality embryos to total embryos were significantly higher in the HP-hMG group $(p=0.006$, Table 3 ). The fertilization rate of rec-FSH group was significantly higher than HP-hMG group ( $p=0.001$, Table 3$)$. Embryo transfer was performed in 40 patients in the rec-FSH group and 28 patients in HP-hMG group. 3 patients in the rec-FSH group and 12 patients 
in the HP-hMG group did not have embryo transfer due to lack of embryo. Fertilization failure was the main reason for embryo transfer cancellation. In 64 patients, embryo transfer was easy, while in 4 patients it was difficult.

In conclusion, no significant differences were observed between the study groups in terms of implantation, biochemical and clinical pregnancy, and ongoing pregnancy rates per randomized patient (Table 4).

\section{Discussion}

In the last decade, gonadotropins used in controlled ovarian stimulation have been increasing in number. Beside the recombinant preparations such as rec-FSH, rec-LH and h-HMG human-derived preparations have entered the markets. Highly purified human menopausal gonadotropin (HP-hMG) has been the last preparation that was used for infertility (11). The aim of this study was to compare the effect of rec-FSH and HP-hMG in the IVF protocol on the quality of acquired embryo and pregnancy outcome. Factors that can influence the outcomes were limited with the intention of providing homogenization in the study groups. In the latest meta-analysis, the ongoing pregnancy rate was $5 \%$ higher in the patients treated with HP-hMG than rec-FSH. The ongoing pregnancy rates were $27 \%$ with HP-hMG and $22 \%$ with rec-FSH, but no statistical difference was established (12). The first study to evaluate the quality of embryo in the study groups stimulated with rec FSH and HP-hMG was carried out by Ziebe et al. They observed the positive effect of gonadotropin with LH activity on the number of blastomeres and degree of fragmentation (13). In this study, the ongoing pregnancy rates were $38.9 \%$ in the rec-FSH group and $25.3 \%$ in the HP-hMG group. There was no statistical difference between the two groups ( $\mathrm{p}>0.05)$ (Table 4).

Our study included only patients suitable for in vitro fertilization. The patients requiring Intra Cytoplasmic Sperm Injection (ICSI) were excluded. Furthermore, the patients who did not have embryo transfer were suitable for cancellation cycle criteria. These criteria included poor ovarian response and lack of qualified embryo. Andersen et al. found that the rate of embryo transfer in patients stimulated with rec-FSH and HP-hMG was $82 \%$ (14). In our study, the rate of embryo transfer was $90 \%$ in the rec-FSH group and $90.3 \%$ in the HP-hMG group. Between the two groups, no statistical difference was observed. Our outcomes are compatible with other studies (Table 3). Another argument is the effect of LH activity on ovarian response. There is insufficient information regardingt the number and development potential of retrieved oocytes. In 2004, Platteau et al. reported that the number of retrieved oocytes was higher in the patients stimulated with rec-FSH than HP-hMG. Interestingly, the number of top-quality embryo was higher in the HP-hMG group, while the number of retrieved oocytes was higher in rec-FSH group. According to this finding, the positive effect of LH activity on development and quality of oocytes was stated (5). Ziebe et al. reported that the mean number of retrieved oocytes was 11.8 in the rec-FSH group, whereas this was 10 in the HP-hMG group. The difference between the two groups were significant statistically $(p<0.001)$. Also, they found
Table 2. Clinical parameters during stimulation in the groups

\begin{tabular}{|c|c|c|c|}
\hline & $\begin{array}{c}\text { rec-FSH } \\
(\text { mean } \pm s d)\end{array}$ & $\begin{array}{l}\text { HP-hMG } \\
(\text { mean } \pm s d)\end{array}$ & $\mathbf{p}$ \\
\hline $\begin{array}{l}\mathrm{E}_{2}(\mathrm{nmol} / \mathrm{l}) \text { in day } \\
\text { of } \mathrm{hCG}\end{array}$ & $2018.63 \pm 1083.77$ & $1562.44 \pm 948.94$ & $0.041^{*}$ \\
\hline $\begin{array}{l}\text { Endometrial } \\
\text { thickness (mm) } \\
\text { in day of hCG }\end{array}$ & $10.48 \pm 2.21$ & $9.92 \pm 2.57$ & 0.282 \\
\hline Total dose (IU) & $3287.79 \pm 1012.97$ & $3471.72 \pm 1121.80$ & 0.427 \\
\hline $\begin{array}{l}\text { Avarage daily } \\
\text { dose (IU) }\end{array}$ & $348.95 \pm 86.46$ & $365.09 \pm 87.60$ & 0.392 \\
\hline
\end{tabular}

Table 3. Oocyte and embryo parameters after stimulation in the groups

\begin{tabular}{|c|c|c|c|}
\hline & $\begin{array}{c}\text { rec-FSH } \\
\text { mean } \pm \text { sd }\end{array}$ & $\begin{array}{l}\text { HP-hMG } \\
\text { mean } \pm \text { sd }\end{array}$ & $\mathbf{p}$ \\
\hline Oocytes retrieved & $9.24 \pm 5.50$ & $6.88 \pm 5.08$ & $0.029 *$ \\
\hline Mature oocytes & $7.88 \pm 4.95$ & $5.24 \pm 4.10$ & $0.010^{*}$ \\
\hline $\begin{array}{l}\text { Number of oocytes } \\
\text { fertilized }\end{array}$ & $4.22 \pm 3.57$ & $1.87 \pm 1.96$ & $0.001 *$ \\
\hline Embryos on day 3 (total) & $6.41 \pm 4.03$ & $3.43 \pm 3.15$ & 0.116 \\
\hline Embryos Transferred & $2.25 \pm 0.80$ & $2.18 \pm 0.90$ & 0.825 \\
\hline $\begin{array}{l}\text { Top quality embryos count } \\
\text { in embryos on day } 3 \text { (total) }\end{array}$ & $2.84 \pm 3.36$ & $2.44 \pm 2.00$ & 0.865 \\
\hline \multirow{2}{*}{$\begin{array}{l}\text { Top quality embryos/Total } \\
\text { embryos }\end{array}$} & $45.89 \pm 37.95$ & $71.31 \pm 34.63$ & $0.006^{*}$ \\
\hline & n (\%) & n (\%) & \\
\hline Fertilization rate (\%) & $40(90.9)$ & $25(58.1)$ & $0.001 *$ \\
\hline Embryos transferred (\%) & $40(90.9)$ & $28(90.3)$ & 1.000 \\
\hline
\end{tabular}

Table 4. Efficacy end points in the groups

\begin{tabular}{|c|c|c|c|c|}
\hline & & $\begin{array}{c}\text { rec-FSH } \\
\text { n } \%\end{array}$ & $\begin{array}{c}\text { HP-hMG } \\
\mathbf{n} \%\end{array}$ & $\mathbf{p}$ \\
\hline \multirow{4}{*}{$\begin{array}{l}\text { Biochemical } \\
\text { pregnancy }\end{array}$} & \multirow[t]{2}{*}{+} & 10 & 8 & \multirow{4}{*}{0.839} \\
\hline & & 26.3 & 28.6 & \\
\hline & \multirow[t]{2}{*}{-} & 28 & 20 & \\
\hline & & 73.3 & 71.4 & \\
\hline \multirow{4}{*}{$\begin{array}{l}\text { Clinical } \\
\text { pregnancy }\end{array}$} & \multirow[t]{2}{*}{+} & 8 & 6 & \multirow{4}{*}{0.812} \\
\hline & & 25.8 & 23.1 & \\
\hline & \multirow[t]{2}{*}{-} & 23 & 20 & \\
\hline & & 74.2 & 76.9 & \\
\hline \multirow{4}{*}{$\begin{array}{l}\text { Ongoing } \\
\text { pregnancy }\end{array}$} & \multirow[t]{2}{*}{+} & 7 & 6 & \multirow{4}{*}{0.826} \\
\hline & & 38.9 & 35.3 & \\
\hline & \multirow[t]{2}{*}{-} & 11 & 11 & \\
\hline & & 61.1 & 64.7 & \\
\hline
\end{tabular}


that the fertilization rate was $51.6 \%$ in the HP-hMG group and $52.6 \%$ in the rec-FSH group $(p=0.065)(13)$. In the same study, the mean numbers of cells with 2 pronucleus at the 20th hour were $5.1 \pm 4.0$ in the $\mathrm{HP}-\mathrm{hMG}$ group, $6.0 \pm 4.3$ in the rec-FSH group (13). In our study, the proportion of fertilization rate was $90.9 \%$ in the rec-FSH group, $58.1 \%$ in the HP-hMG group. There were significant statistical differences $(p=0.001$, Table 3$)$. The mean numbers of cell with 2 pronucleus at the 20th hour were $1.87 \pm 1.96$ in the HP-hMG group and $4.22 \pm 3.57$ in the rec-FSH group. Between the two groups, patients stimulated with recFSH have a statistically higher fertilization number $(p<0.01)$. The mean number of oocytes retrieved was significantly lower in the HP-hMG group compared with the rec-FSH group $(\mathrm{p}<0.05$, Table 3). The numbers of mature oocytes differ between the treatment groups, and was found higher in the HP-hMG group than the rec-FSH group $(\mathrm{p}<0.005)$, but the proportion of mature oocytes to total oocytes retrieved was similar in the two groups $(\mathrm{p}=0.05$, Table 3$)$. The mechanisms whereby the LH activity could mediate improvements in some oocyte/embryo quality parameters in IVF cycles are not yet fully understood. Cumulus cells are considered an ideal surrogate for assessment of oocyte development potential. It is speculated that a set of cumulus genes may determine oocyte maturation, fertilization potential, and embryo quality (15). Magier et al. detected that cumulus cells have a positive effect on embryo development (16). Furthermore, cumulus cells and cytoplasmic maturation of oocytes that may be directed with LH activity was considered in some studies (5). Ziebe et al. obtained a higher percentage of top-quality embryos per oocyte retrieved from stimulation with HP-hMG. The subgroup of top-quality embryos obtained from HP-hMG-treated women was associated with increased ongoing implantation and pregnancy rates in comparison with rec-FSH-treated women (13). Formerly, articles had declared that LH activity with the effect of RecFSH increased the rates of implantation and pregnancy (17). In our study, the proportion of top-quality embryos per obtained oocyte in patients treated with HP-hMG and rec-FSH was $28.4 \%$ and $20.37 \%$, respectively. We did not observe a statistical difference between the two groups $(p>0.05)$. The rate of top-quality embryo to total embryo was $45.8 \%$ in rec-FSH and this rate was $71.31 \%$ in HP-hMG group. The higher proportion of HP-hMG group was significant statistically $(\mathrm{p}<0.001$, Table 3). Information on ongoing pregnancy rate was not relevant between the rec-FSH and HP-hMG groups. In their study, Andersen and Coworkers conducted a research in which the ongoing pregnancy rate was $27 \%$ in the HP-hMG group and $22 \%$ in the rec-hMG group (14). In our study, the clinical pregnancy rates were 25.8 in the rec-FSH and 23.1 in the HP-hMG groups and the ongoing pregnancy rates were 38.9 and 35.3 , respectively. However, the superiority of rec-FSH on the clinical and ongoing pregnancy rates are not shown statistically $(p>0.05)$.

In conclusion, the higher oocyte yield with rec-FSH does not result in more high quality embryos. LH activity with the combination of FSH activity positively affected the oocyte and embryo maturation. Therefore, when we compare the clinical and ongoing pregnancy rates, there is no inferiority of HP-hMG in controlled ovarian stimulation.
Conflict of interest

None declared.

\section{References}

1. van Wely M, Westergaard LG, Bossuyt PM, van der Veen F. Effectiveness of human menopausal gonadotropin versus recombinant follicle-stimulating hormone for controlled ovarian hyperstimulation in assisted reproductive cycles: a meta-analysis. Fertil Steril. 2003; 80: 1086-93. [CrossRef]

2. Westergaard LG, Erb K, Laursen SB, Rex S, Rasmussen PE. Human menopausal gonadotropin versus recombinant follicle-stimulating hormone in normogonadotropic women down-regulated with a gonadotropinreleasing hormone agonist who were undergoing in vitro fertilization and intracytoplasmic sperm injection: a prospective randomized study. Fertil Steril. 2001; 76: 543-9. [CrossRef]

3. Bosch E, Vidal C, Labarta E, Simon C, Remohi J, Pellicer A. Highly purified $\mathrm{hMG}$ versus recombinant FSH in ovarian hyperstimulation with GnRH antagonists-a randomized study. Hum Reprod. 2008; 23 : 2346-51. [CrossRef]

4. Fleming R, Lloyd F, Herbert M, Fenwick J, Griffiths T, Murdoch A. Effects of profound suppression of luteinizing hormone during ovarian stimulation on follicular activity, oocyte and embryo function in cycles stimulated with purified follicle stimulating hormone. Hum Reprod. 1998; 13: 1788-92. [CrossRef]

5. Platteau P, Andersen AN, Balen A, Devroey P, Sørensen P, Helmgaard L et al. Menopur Ovulation Induction (MOI) Study Group. Similar ovulation rates, but different follicler development with highly purified menotrophin compared with recombinant FSH in WHO group II anovulatory infertility: a randomized controlled study. Hum Reprod. 2006; 21: 1798-804. [CrossRef]

6. Filicori M, Cognigni GE, Gamberini E, Parmegiani L, Troilo E, Roset B. Efficacy of low-dose human chorionic gonadotropin alone to complete controlled ovarian stimulation. Fertil Steril. 2005; 84: 394-401. [CrossRef]

7. Filicori M, Cognigni GE, Pocognoli P, Tabarelli C, Spettoli D, Taraborrelli $\mathrm{S}$ et al. Modulation of folliculogenesis and steroidogenesis in women by graded menotrophin administration. Hum Reprod. 2002; 17: 2009-15. [CrossRef]

8. Hompes PG, Broekmans FJ, Hoozemans DA, Schats R; FIRM group. Effectiveness of highly purified human menopausal gonadotropin vs. recombinant follicle-stimulating hormone in first-cycle in vitro fertilization- intracytoplasmic sperm injection patients. Fertil Steril. 2008; 89: 1685-93. [CrossRef]

9. Chappel SC, Howles C. Reevaluation of the roles of luteinizing hormone and follicle-stimulating hormone in the ovulatory process. Hum Reprod. 1991; 6: 1206-12.

10. Regan L, Owen EJ, Jacobs HS. Hypersecretion of luteinising hormone, infertility, and miscarriage. Lancet. 1990; 336: 1141-4. [CrossRef]

11. Kilani Z, Dakkak A, Glunaim S, Cognigni GE, Tobarelli C, Parmegiani L et al. A prospective, randomized, controlled trial comparing highly purified hMG with rec-FSH in women undergoing ICSI: ovarian response \& clinical outcomes. Hum Reprod. 2003; 18: 1194-9. [CrossRef]

12. Vav Wely M, Westergard LG, Bossuyt PMM, Van Der Veen F. Human menopausal gonadotropin versus recombinant follicle stimulation hormone for ovarian stimulation in assisted reproductive cycles. Fertil Steril. 2003; 80: 1121-2. [CrossRef]

13. Ziebe S, Lundin K, Janssens R, Helmgaard L, Arce JC; MERIT (Menotrophin vs Recombinant FSH in vitro Fertilisation Trial) Group. Influence of ovarian stimulation with HP-hMG or recombinant FSH on embryo quality parameters in patients undergoing IVF. Hum Reprod. 2007; 22: 2404-13. [CrossRef]

14. Andersen AN, Devroey P, Arce JC. Clinical outcome of following stimulation with highly purified hMG or recombinant $\mathrm{FSH}$ in pa- 
tients undergoing IVF: a randomized assessor - blind controlled trial. Hum Reprod. 2006; 21: 3217-27. [CrossRef]

15. McKenzie LJ, Pangas SA, Carson SA, Kovanci E, Cisneros P, Buster JE et al. Human cumulus granulosa cell gene expression: a predictor of fertilization and embryo selection in women undergoing IVF. Hum Reprod. 2004; 19: 2869-74. [CrossRef]
16. Magier S, Van Der Van HH, Diedrich K, Krebs D. Significance of cumulus oophorus in in vitro fertilization and oocyte viability and fertility. Hum Reprod. 1990; 5: 847-52.

17. Gordon UD, Harrison RF, Fawzy M, Hennely B, Gordon AC. A randomized prospective accessor- blind evaluation of luteinizing hormone dosage in in vitro fertilization outcome. Fertil Steril. 2001; 75: 324-31. [CrossRef] 